\title{
Pemodelan Matematika Perpindahan Panas pada Stenosis Arteri Karotis
}

Author:
Dwi Indrianti ${ }^{1}$
Arif Fatahillah ${ }^{2}$
Susi Setiawani

Affiliation:
1,2,3 University of Jember, East
Java, Indonesia
Corresponding author:
Dwi Indrianti,
dwiindrianti07@ gmail.com
Dates:
Received: $28 / 2 / 2021$
Accepted: $14 / 3 / 2021$
Published: $16 / 3 / 2021$

\begin{abstract}
Abstrak. Stenosis arteri karotis adalah penyempitan lumen (permukaan dalam) arteri karotis. Biasanya stenosis disebabkan oleh aterosklerosis, yaitu plak ateromatosa akibat peradangan yang terdiri dari nekrotik, lemak, dan kristal kolesterol. Tersumbatnya lumen arteri membuat otak kekurangan suplai darah sehingga menyebabkan kerusakan fungsi otak. Terkadang, suplai darah dalam jangka waktu lama dapat menyebabkan kerusakan permanen pada jaringan pembuluh darah di otak. Stenosis juga merupakan ancaman yang berbahaya bagi kesehatan, yaitu stroke. Arteri karotis yang menyempit memiliki suhu tertentu. Munculnya pemodelan matematika sebagai ilmu baru merupakan salah satu alternatif untuk menyelesaikan masalah tersebut. Dengan pemodelan matematis, peneliti memperoleh rumus yang menggambarkan keadaan perpindahan kalor pada arteri karotis menurut kondisi sebenarnya tanpa memperhatikan faktor penting dalam sistem. Dalam studi ini, model matematika dibangun berdasarkan masalah di atas untuk menganalisis perpindahan panas yang terjadi pada arteri karotis akibat stenosis.
\end{abstract}

Kata kunci: Stenosis arteri karotis, Pemodelan matematika, elemen hingga

Abstract. Carotid artery stenosis is the narrowing of the lumen (inner surface) of the carotid artery. Usually stenosis is caused by atherosclerosis, which is an atheromatose plaque due to inflammation consisting of necrotics, fats and cholesterol crystals. Occlusion of arterial lumens makes the brain lack blood supply causing damage to brain function. Sometimes, a long period of blood supply can cause permanent damage to vascular tissue in the brain. Stenosis also poses a dangerous threat to health, namely stroke. Narrowed carotid arteries have a certain temperature. The emergence of mathematical modeling as a new science is one alternative to solving this problem. By mathematical modeling, researchers obtained a formula that describes the state of heat transfer in the carotid artery according to the actual conditions regardless of the important factors in the system. In this study, a mathematical model was built on the above problem to analyze heat transfer that occurs in the carotid artery due to stenosis.

Keywords: Carotid artery stenosis, Mathematical modeling, Finite element

\section{J0M \\ This work is licensed under a Creative Commons Attribution-ShareAlike 4.0 International License. \\ Read online: \\ https://jurnal.unej.ac.id/index.php/JOMEAL/index or scan barcode beside.}

How to cite this article:

Indrianti, D., Fatahillah, A., \& Setiawani, S. (2021). Pemodelan Matematika Perpindahan Panas pada Stenosis Arteri Karotis. Journal of Mathematics Education and Learning, 1(1), 92-97. Retrieved from https://jurnal.unej.ac.id /index.php/JOMEAL/article/view/24379 


\section{Pendahuluan}

Matematika merupakan salah satu disiplin ilmu yang penting dalam kehidupan sehari-hari yang didefinisikan dengan jelas, cermat, akurat dam representasinya banyak menggunakan simbolsimbol (Fatahillah, Setiawani, \& Fatihah, 2015). Matematika merupakan ilmu yang mendasari pengembangan ilmu-ilmu lainnya. Konsep dan prinsip yang ada pada ilmu matematika banyak digunakan untuk menyelesaikan permasalahan dalam kehidupan sehari-hari (Husein, Fatahillah, \& Setiawani, 2020). Salah satu ilmu yang menggunakan konsep matematika dalam penyelesaian permasalahannya adalah ilmu kedokteran.

Ilmu kedokteran merupakan ilmu yang mempelajari tentang cara mempertahankan kesehatan manusia, penyakit dan cara menyembuhkannya. Ilmu ini meliputi pengetahuan tentang sistem tubuh manusia, serta penyakit dan cara mengobatinya (Hasan, 2018). Banyak penyakit atau permasalahan kesehatan dalam tubuh manusia yang ditemukan dalam ilmu kedokteran. Salah satu bagian tubuh manusia yang dapat mengalami permasalahan kesehatan adalah pembuluh darah arteri karotis. Penyakit yang dapat terjadi pada arteri karotis adalah stenosis arteri karotis.

Arteri karotis adalah pemasok utama darah beroksigen ke otak manusia. Arteri karotis berasal dari lengkungan aorta dan bergerak ke atas di kedua sisi leher sebagai arteri karotis umum atau Common Carotid Artery (CCA), yang bercabang ke dalam arteri karotis internal atau Internal Carotid Artery (ICA) dan arteri karotis eksternal atau External Carotid Artery (ECA) yang masing-masing memasok darah ke otak dan wajah (Masuhudi, Fatahillah, \& Setiawan, 2018).

Stenosis yang berarti penyempitan, pada umumnya digunakan dalam istilah medis untuk menjelaskan penyempitan pada daerah tertentu (Fatahillah,. dkk, 2019). Stenosis arteri karotis adalah penyempitan lumen (permukaan bagian dalam) dari arteri karotis. Biasanya stenosis disebabkan oleh atherosclerosis, yaitu suatu plak atheromatosa akibat adanya peradangan yang terdiri dari nekrotik, lemak dan kristal kolesterol (Hasan, 2018). Oklusi lumen arteri membuat otak kekurangan suplai darah yang menyebabkan kerusakan fungsi otak. Terkadang, dalam periode yang lama dari bekurangnya pasokan darah dapat menyebabkan kerusakan permanen pada jaringan vaskuler yang ada di otak. Stenosis juga menyebabkan ancaman yang berbahaya bagi kesehatan, yaitu stroke (Masyhudi, fatahillah, \& Setiawan, 2018). Menurut data statistik menyatakan bahwa sekitar 15 juta orang di seluruh dunia mengalami stroke setiap tahun. Dua pertiga dari kematian akibat stroke terjadi di negara-negara kurang berkembang. Diperkirakan setiap tahun terjadi 500.000 penduduk terkena serangan stroke di Indonesia, sekitar 2,5\% atau 125.000 orang meninggal, dan sisanya cacat ringan maupun berat (Husein, Fatahillah, \& Setiawani, 2020). Gambar 1 menunjukkan stenosis yang terjadi pada arteri karotis. 


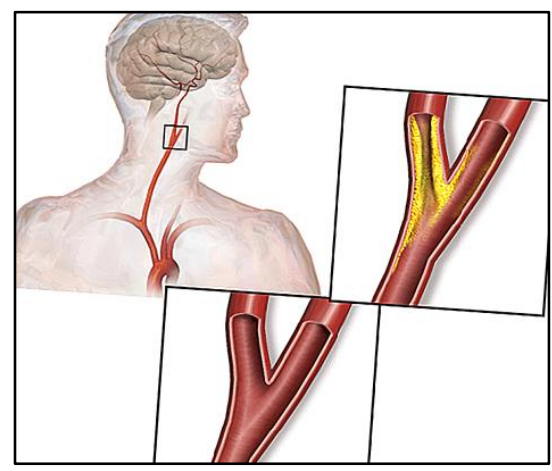

Gambar 1. Stenosis arteri karotis

Perpindahan panas stenosis arteri karotis dapat dilakukan dengan metode eksperimental dan simulasi numerik. Metode eksperimental dilakukan dengan eksperimen yang dilakukan di rumah sakit dan laboratorium yang membutuhkan biaya mahal. Jika dibandingkan, simulasi numerik memiliki keunggulan dalam fleksibilitas dan biaya. Simulasi numerik dapat dilakukan dengan menggunakan komputer.

Cabang ilmu matematika sangat beraneka ragam, salah satunya yaitu pemodelan matematika. Pemodelan matematika merupakan cabang matematika yang berusaha untuk merepresentasikan dan menjelaskan sistem fisik atau permasalahan agar menjadi lebih tepat (Brahmanto, Fatahillah, \& Dafik, 2017). Model matematika merupakan representasi dari permasalahan nyata yang dijabarkan dalam bentuk simbol dan pernyataan matematika (Fatahillah, Setiawani, \& Damayanti, 2018). Proses pemodelan dapat dilakukan dengan menerjemahkan fenomena atau masalah nyata menjadi masalah matematika. Biasanya pemodelan matematika disajikan dalam bentuk persamaan-persamaan (Hasan, 2018). Model matematika yang telah dibentuk akan diselesaikan menggunakan suatu metode agar lebih mudah dalam menemukan solusinya. Metode yang digunakan adalah metode elemen hingga.

Metode elemen hingga merupakan suatu metode pendekatan numerik yang mendasarkan permasalahan pada setiap bagian dari elemen yang disebut dengan elemen hingga (Damai, Asrizal, \& Yohandri, 2017). Metode elemen hingga berlaku untuk semua jenis persamaan diferensial parsial dan nonlinear dalam fisika dan teknik. Konsep metode ini adalah menyelesaikan suatu permasalahan dengan membagi daerah obyek yang dianalisa menjadi bagian-bagian kecil (nodes) yang terhingga, biasanya segitiga atau segiempat. Bagian-bagian tersebut kemudian dianalisa dan solusinya digabungkan kembali untuk mendapatkan penyelesaian dari seluruh daerah (Pitriani, 2016).

Masalah yang dikaji pada penelitian ini adalah membuat dan menganalisis model matematika perpindahan panas yang terjadi pada arteri karotis akibat adanya stenosis, dengan rumusan masalah yaitu bagaimana model matematika perpindahan panas stenosis arteri karotis. Berdasarkan uraian di atas, tujuan dari penelitian ini adalah untuk mengetahui model matematika perpindahan panas 
stenosis arteri karotis. Model matematika perpindahan panas stenosis arteri karotis dibangun dari persamaan energi.

$$
\begin{aligned}
& \frac{\partial \phi_{0}}{\partial t}+[\text { pure } \text { rate }]=\sum S \\
& \frac{\partial \phi_{0}}{\partial t}+[\text { input }- \text { output }]=\sum S
\end{aligned}
$$

\section{Metode Penelitian}

Metode penelitian merupakan tahap yang dilakukan untuk mendapatkan data yang akan dianalisis untuk sampai pada kesimpulan yang konsisten dengan tujuan penelitian. Penelitian ini merupakan jenis penelitian simulasi. Penelitian simulasi merupakan penelitian yang dilakukan untuk mencari gambaran melalui sebuah sistem yang berskala kecil atau sederhana dimana di dalam model yang digunakan akan dilakukan manipulasi atau control untuk mengetahui pengaruhnya (Damai, Asrizal, \& Yohandri, 2017).

Langkah pertama yang dilakukan dalam penelitian ini adalah mengumpulkan data dan teoriteori yang mendukung, sehingga dapat dilakukan pendesainan model matematika perpindahan panas pada arteri karotis akibat adanya stenosis. Langkah selanjutnya yaitu menyelesaikan model matematika yang telah dibentuk.

\section{Hasil dan Pembahasan}

Pembentukan model matematika perpindahan panas pada arteri karotis akibat adanya stenosis didasarkan pada persamaan energi. Gambar 2 merupakan diagram alir untuk perpindahan panas pada arteri karotis akibat adanya stenosis. Energi yang masuk adalah $\frac{\partial v \phi_{s}}{\partial y}$ dan untuk energi yang keluar adalah $\frac{\partial v \phi_{n}}{\partial y}$. Persegi panjang melambangkan arteri yang didalamnya terdapat perpindahan panas. Dengan mensubstitusikan pure rate ke persamaan 1 maka diperoleh :

$$
\begin{aligned}
& \frac{\partial \phi_{0}}{\partial t}+\left[\frac{\partial v \phi_{s}}{\partial y}-\frac{\partial v \phi_{n}}{\partial y}\right]=\sum S \\
& \frac{\partial \phi_{0}}{\partial t}+\frac{\partial v \phi_{y}}{\partial y}=\sum S
\end{aligned}
$$

Source $(S)$ merupakan energi yang bekerja pada sistem. Energi-energi yang bekerja pada proses ini adalah:

1. Temperatur $(\mathrm{T})$

2. Panas divusitas darah $(\alpha)$

sehingga, persamaan energi yang bekerja adalah : 


$$
\sum S=\alpha \frac{\partial^{2} T}{\partial y^{2}}+\left(\left(\rho_{b} \cdot C_{p b} \cdot \omega_{b}\right)\left(T_{a}-T\right)\right)+q m+R(z)
$$

dimana :

$$
\begin{aligned}
& \alpha=\frac{k}{\rho C_{p b}} \\
& R(z)=R_{0}-\frac{\delta s}{2}\left(1+\cos \frac{2 \pi}{L_{0}}\left(z-d-\frac{L_{0}}{2}\right)\right)
\end{aligned}
$$

Dengan mensubstitusikan persamaan 6 ke persamaan 5 maka didapat persamaan sebagai berikut:

$$
\begin{aligned}
\sum S= & \frac{k}{\rho C_{p b}} \frac{\partial^{2} T}{\partial y^{2}}+\left(\left(\rho_{b} \cdot C_{p b} \cdot \omega_{b}\right)\left(T_{a}-T\right)\right)+q m+R_{0}- \\
& \frac{\delta s}{2}\left(1+\cos \frac{2 \pi}{L_{0}}\left(z-d-\frac{L_{0}}{2}\right)\right)
\end{aligned}
$$

Selanjutnya substitusikan persamaan 7 ke persamaan 4 didapat:

$$
\begin{aligned}
\frac{\partial \phi_{0}}{\partial t}+\frac{\partial v \phi_{y}}{\partial y}= & \sum \frac{k}{\rho C_{p b}} \frac{\partial^{2} T}{\partial y^{2}}+\left(\left(\rho_{b} \cdot C_{p b} \cdot \omega_{b}\right)\left(T_{a}-T\right)\right)+q m+R_{0}- \\
& \frac{\delta s}{2}\left(1+\cos \frac{2 \pi}{L_{0}}\left(z-d-\frac{L_{0}}{2}\right)\right)
\end{aligned}
$$

Persamaan 8 di atas merupakan model matematika perpindahan panas stenosis arteri karotis.

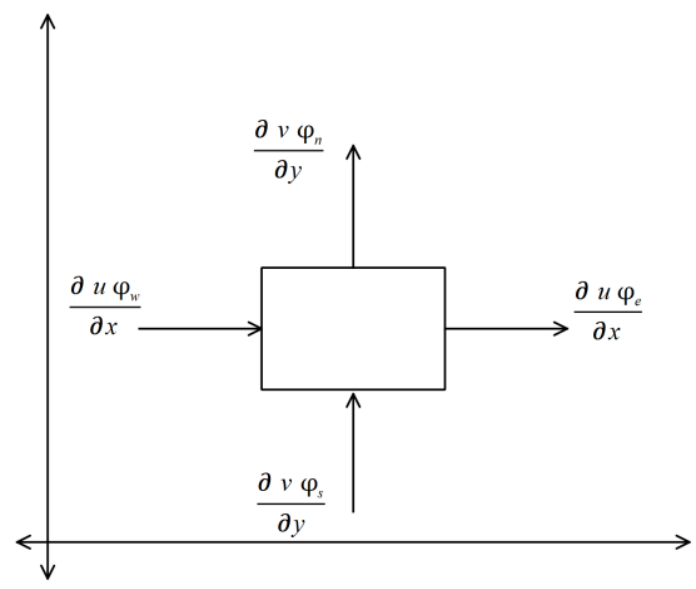

Gambar 2. Diagram Alir Perpindahan Panas Stenosis Arteri Karotis

\section{Kesimpulan}

Berdasarkan penelitian yang telah dilakukan diharapkan agar melakukan penelitian yang menganalisis faktor lain selain perpindahan panas. Model matematika pada perpindahan panas stenosis arteri karotis diperoleh dari persamaan energi. Berdasakan hasil penelitian maka model matematika perpindahan panas pada arteri karotis akibat adanya stenosis yang diperoleh yaitu: 


$$
\begin{gathered}
\frac{\partial \phi_{0}}{\partial t}+\frac{\partial v \phi_{y}}{\partial y}=\sum \frac{k}{\rho C_{p b}} \frac{\partial^{2} T}{\partial y^{2}}+\left(\left(\rho_{b} \cdot C_{p b} \cdot \omega_{b}\right)\left(T_{a}-T\right)\right)+q m+R_{0}- \\
\frac{\delta s}{2}\left(1+\cos \frac{2 \pi}{L_{0}}\left(z-d-\frac{L_{0}}{2}\right)\right)
\end{gathered}
$$

\section{Daftar Pustaka}

Amirullah, I., A. Fatahillah, dan T. B. Setiawan. (2019). Pemodelan Matematika Aliran Darah pada Arteri Koroner Akibat Pemsangan Stent. Kadikma. 10(1): 68-73.

Brahmanto, J., A. Fatahillah, dan Dafik. 2017. Pemodelan Matematika Aliran Fluida pada Radiator Mobil Tipe SR (Single Row). Kadikma. 8(1): 112-117.

Damai, A., Asrizal, dan Yohandri. (2017). Simulasi Desain Antena Microstrip Array dengan Tingkat Sidelobe Rendah untuk Sensor Synthetic Aperture Radar. Pillar of Physics. 10: 1-8.

Fatahillah, A., S. Setiawani, dan R. Damayanti. (2018). Mathematical Model Analysis of Fluid Flow in Edamame Hydrofluidization Using Finite Element Method. Journal of Physics Conf. Series. 1211(12021): 1-6.

Fatahillah, A., S. Setiawani, A.S. Mandala, S. Suharto, R. P. Murtikusuma, L. N. Safrida, S. Hussen, dan R. Adawiyah. (2019). Numerical Analysis of Blood Flow in Intracranial Artery Stenosis Affected by Ischemic Stroke Using Finite Element Method. Journal of Physics. 1218: 1-7.

Fatahillah, A., S. Setiawani, dan R. Damayanti. (2018). Mathematical Model Analysis of Fluid Flow in Edamame Hydrofluidization Using Finite Element Method. Journal of Physics. 1211: 1-6.

Fatahillah, A., S. Setiawani, N. N. Fatihah. (2015). Pemodelan dan Simulasi Numerik Sebaran Air Panas Spray Pond Menggunakan Metode Volume Hingga. Saintifika. 7(1): 20-28.

Hasan, J. P. (2018). Analisis Numerik Aliran Darah pada Arteri Karotis Akibat Pemasangan STENT Menggunakan Metode Elemen Hingga untuk Mengasah Kemampuan TCK. Skripsi. Jember: Fakultas Keguruan dan Ilmu Pendidikan.

Husein, T. A. A., A. Fatahillah, S. Setiawani. (2020). Pemodelan Matematika Aliran Darah pada Arteri Perifer Akibat Pemasangan Stent. Saintifika. 22(1): 52-58.

Masyhudi, M. A., A. Fatahillah, T. B. Setiawan. (2018). Pemodelan Matematika Penyebaran Polutan Udara di Kawasan PLTU Menggunakan Metode Volume Hingga. Kadikma. 9(3): 194-203.

Pitriani. (2016). Kemampuan Pemodelan Matematika dalam Realistic Mathematics Education (RME). JES-MAT. 2(1): 65-82.

Pratiwi, M. A. (2019). Penerapan Range of Motion (ROM) untuk Meningkatkan Kekuatan Otot pada Pasien Stroke Non Hemoragik di Wilayah Puskesmas Sruweng. Skripsi. Gombong: Program Studi DIII Keperawatan STIKES Muhammadiyah Gombong.

Saxena, A., E. Y. K. Ng, M. Mathur, C. Manchanda, dan N. A. Jajal. (2019). Effect of Carotid Artery Stenosis on Neck Skin Tissue Heat Transfer. International Journal of Thermal Science. 145: $1-12$.

White, F. M. (2011). Fluid Mechanics, Seventh Edition. New York: The McGraw-Hill Companies. 